katpantovic@gmail.com

Катарина ПАНТОВИТ

\title{
СИБЕ МИЛИЧИЋ НА РАСКРШЋУ МЕДИТЕРАНА И БАЛКАНА
}

Институт за књижевност

и уметност, Београд

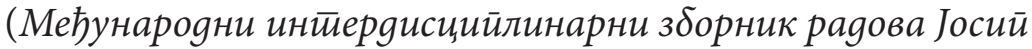

Сибе Миличић: време, ирростиор, суgбине, Београд: Институт за књижевност и уметност, Универзитетска библиотека „Светозар

Марковић“; Zagreb: Filozofski fakultet Sveučilišta u Zagrebu,

Centar za komparativnohistorijske i interkulturne studije, 2018)

Међународни интердисциплинарни зборник радова Јосий Сuळе Миличић: време, ирростиор, суgбине резултат је сарадње Института за књижевност и уметност у Београду, Универзитетске библиотеке „Светозар Марковић“ у Београду и Центра за компаративнохисторијске и интеркултурне студије Филозофског факултета Свеучилишта у Загребу. Научни скуп међународног карактера посвећен овом песнику, писцу, уметнику и дипломати одржан је 2. јуна 2017. године, а зборник је објављен 2018. године и представља прву књигу у оквиру новопокренуте едиције Лимес која представља дугорочни издавачки план с циљем да отвори нове истраживачке и интердисциплинарне хоризонте. Иако тренутно постоји само једно издање, ова инвентивна едиција карактеристична је захваљујући специфичном методолошком приступу који је окупио несумњиво подстицајна мултидисциплинарна и компаративна истраживања. Посебност овог издања огледа се и у неконвенционалном формату књиге која је обогаћена фотографијама Јосипа Сибета Миличића и репродукцијама његових графика и слика.

Није случајно што је баш овај контроверзни песник, прозаиста, есејиста, сликар и дипломата југословенског међуратног периода (1886-1944) одабран за стожерну фигуру првог зборника нове едиције. Идејна окосница и концепт Лимеса (од латинске речи за праг, граничник) јесте превазилажење граница, и то на више равни, пре свега оној која се тиче самог аутора: Сибе Миличић је амалгамисао медитерански и средњоевропски завичајни простор и онај простор где је живео, као и уметничке и научне дисциплине у којима се огледао. Реч је, такође, о аутору који припада „лиминалном“ српско-хрватском књижевноисторијском наслеђу у коме ни дан-данас није у потпуности ситуиран. С друге стране, концепт едиције Лимес примењен је и на текстуалној, односно методолошкој равни, с обзиром на то да је велики број радова интердисциплинарног типа, 
те повезује Миличићев опус с историјским, музичким, ликовним, преводилачким и политичким проседеом. У зборнику су објављени радови 21 аутора из Србије, Хрватске, Италије и Црне Горе, који су подељени у пет поглавља по тематским и научним областима. Уреднице овог зборника, проф. др Сања Роић с Филозофског факултета у Загребу и др Светлана Шеатовић, виши научни сарадник на Институту за књижевност и уметност у Београду, у предговору истичу неопходност и значај враћања истраживањима о Јосипу Сибету Миличићу, чије је дело неправедно, али симптоматично, досад остало без правог истраживачког упоришта и места у српској и хрватској књижевности. Подсећања ради, Сибе Миличић био је хрватски католик рођен на Хвару и васпитан у оквирима строге језуитске вере, који је, међутим, најплоднији стваралачки период свог живота везао за српско подручје и Београд, тада изузетно активан центар авангардистичких стремљења која су умногоме реконструисала његов уметнички сензибилитет. Прве две збирке поезије (Пјесме, Десей йјесама о Дон Хуану) објавио је на латиничној ијекавици, да би трећу збирку, названу 3, издала Матица српска у Дубровнику на ћириличној екавици, и до 1941. објављује 13 песничких и прозних дела, као и преводна дела Леопардија на екавици у Београду. Миличић је био и дипломата од високог поверења Краљевине Југославије и носилац бројних ордена, а како током Другог светског рата није желео да се приклони НДХ-у, мистериозно је нестао 20. августа 1944. године у партизанској бази у Барију, премда постоје и наводи (Архив Јова Вујошевића у Црној Гори) да је преминуо природном смрћу.

Иако је Миличић у Краљевини Југославији био прихваћен и афирмисан, из потоње социјалистичке Југославије као аутор готово је екскомунициран управо због свог амбивалентног припадања или, прецизније, нейрийаgаға (како проницљиво запажа Јосип Лешић, Миличић је био „премало Хрват“, а „недовољно Србин“). Упркос формирању канона српске и хрватске књижевности, занимљиво је да је Миличић поново остао пренебрегнут упркос својој важности као књижевноисторијска појава, и да се у уџбеницима и студијама спомиње тек спорадично, у склопу навођења групе имена авангардних уметника. Стога овај зборник представља значајан научни подухват који обнавља интересовање за овог аутора и у коме су истраживачи представили и проблематизовали одређена историјска, биографска, књижевна, језичка и ликовна питања.

Први део посвећен је биографским, односно позитивистичким проучавањима која анализирају биографско-историјске прилике и доносе нова сазнања о Миличићевим везама са српском државом и његовим дипломатским функцијама између два рата, о његовом учешћу на Конгресу културних радника 1943. године, и о његовом мистериозном завршетку, односно нестанку и смрти. Б. Ђорђевић у раду „Србија у Рату и Сибе у Србији“, на основу досад непознатих или 
неискоришћених архивских докумената и уз приложена скенирана оригинална писма, пише о мало познатим и занимљивим аспектима живота С. Миличића непосредно по доласку у Београд, као што је његов професорски ангажман у Трећој мушкој гимназији у Београду, одлазак на стипендије и стручна усавршавања, али и тајанствена и провокативна веза с тада најутицајнијим политичарима у Србији. Д. Роксандић и Ш. Пилић у раду „Сибе Миличић на Конференцији културних радника Далмације“ баве се ауторовим антифашистичким, партизанским опредељењем које га је 1943. године одвело на поменуту конференцију на Хвару, никлу из „континуираног стољетног отпора креативне интелигенције ове 'древне крајине“ туђинској млетачкој Италији. На крају, О. Поповић у тексту „Архив Јована Вујошевића у Подгорици и подаци о 'несталом пјеснику““ истражује архивске податке из Легата Јована Лоле Вујошевића, црногорског историчара из Даниловграда, о контроверзној смрти Јосипа Миличића, која је подразумевала вишеструке и узбудљиве, али и контрадикторне, чак и бизарне тврдње. Ослањајући се на истраживања Ј. Лешића који се бавио његовим нестанком, она наводи да постоји претпоставка о „прикривеном злочину партизана који су га наводно ликвидирали“, али открива и нови податак да је Миличић преминуо природном, ненасилном смрћу 1944. године у Барију.

Други део зборника даје одговоре на питања која се уопштено тичу поетике и тематско-мотивске преокупације дела овог аутора, почев од прожимања авангардистичког и медитеранског наслеђа, инкорпорирања ликовних елемената, попут експресионистичког колорита у песнички опус, непотпуног припадања и хрватској, и српској књижевној историји, и места које заузима у српској, превасходно београдској авангарди. У раду „(Дис)хармонија природе и човека у поезији С. Миличића - авангардни и медитерански круг“С. Шеатовић на компаратистички начин сагледава однос идеје „мира и благости“ код Миличића и код Црњанског у Љубави у Тоскани, фокусирајући се на „завичајни простор као модел космичког амбијента“ који је код Миличића надграђен космополитском сликом света прожетом савременим авангардистичким тенденцијама. Без обзира на трауматично ратно искуство, у Миличићевој поезији изнова се витализује весеље, радост као доминантни егзистенцијални принцип, оснажен готово романтичарским заносом у доживљајима природе. По овом културолошком, поетичком и „завичајном“ сензибилитету Миличић је најближи Црњанском, с којим, поред интимног пријатељства, дели и ново осећање света. Т. Мароевић у раду „Црно-бијеле сјене претпостављена колориста - ликовни обриси и додири Сибета Миличића“ анализира ликовне аспекте ауторовог опуса. Упркос кратком временском распону ликовног деловања и недостатку формалног образовања, Миличић је био истакнути ликовни критичар и ликовни уметник авангардног Београда, чији 
„наслови слика сведоче о песниковој имагинацији заокупљеној митским, симболичким, фолклорним или архетипским фигурама и ситуацијама“. Тако се Миличићева ликовна уметност недвосмислено доводи у везу с његовом поезијом, која је иначе изузетно чулна, визуелна и сликовне природе. А. Јерков у занимљивом и есејистичком тексту „Зашто нисам знао шта је пеш, или луди и нечитани Сибе између вечности у Црњанском и непостојања у књижевној историји“, уз многобројна лична запажања вођена асоцијативним принципом, твори својеврсну метапричу о „антропологији књижевне имагинације“ као стожерном елементу који повезује Црњанског и Миличића, запажајући да се „опус С. Миличића претвара у огромну фусноту уз дело великог писца“ и да је књижевни живот овог лиминалної аутора загарантован све док постоји интересовање за Црњанског. Б. Јовић у раду „С. Миличић и (српска) авангарда: огледало у (искривљеном) огледалу“наводи примере како позитивних (Илић, Петровић), тако и негативних (Мицић, Винавер) критика Миличићевог остварења у кругу савременика, чиме се разматра „место и улога, односно рецепција/перцепција Миличића и његовог стваралаштва у сложеној динамици (српске) авангарде“. Јовић истиче да Винаверове и Мицићеве опаске, премда ироничне, неретко гађају у срж Сибетове поетике, која се не испоставља као искључиво авангардистичка (чиме се декларише као оgскачућа) већ као гранична због својих хуманистичко-виталистичких, готово традиционалних елемената.

У трећем делу зборника заступљена су истраживања о Миличићевим везама с немачким, руским и италијанским књижевним правцима, као и о његовом формалном образовању и докторској дисертацији који су изнедрили убедљиве и значајне преводе Леопардија на наш језик. Љ. Бањанин у раду „Миличићев Леопарди“ слика Сибетов портрет свестраног полиглоте и анализира његову докторску дисертацију о италијанском романтичарском песнику одбрањену у Бечу, осврћући се и на могуће разлоге због којих се Миличић определио баш за овог песника: „његова уметничко-професионална стремљења указују на поливалентни интелектуални профил и вишеструк културни идентитет кандидата словенског порекла“. У Миличићевом песништву несумњиво се запажају и одјеци Леопардијеве поезије на стилско-тематском плану, што га као преводиоца доводи у интертекстуалне релације према италијанском песнику. Н. Кабаси у тексту „Сибе Миличић и италијански футуризам“, после краћег увода о рецепцији футуризма у Хрватској, у фокус истраживања ставља период Миличићевог литерарног формирања (1907-1920) и интензивних контаката с италијанском авангардом. Значајно је запажање да он задржава двојак и амбивалентан однос према италијанском футуризму, и од њега присваја само одређене елементе (ономатопејске фигуре и глаголе кретања), док се аутентичнијим, и њему поетичко-идеолошко ближим, чини однос према ру- 
ском футуризму (романтично-импресионистичке и феминистичке тенденције). То сведочи о Миличићевом комбиновању различитих поетика и уметничких атмосфера у циљу стварања властите еклектичне визије. И. Гргић Мароевић у раду „Сибе Миличић, преводилац Леопардијевог 'L'Infinità'“ детаљно анализира и вреднује Миличићеве преводилачке поступке ове чувене Леопардијеве идиле у две верзије, из 1914. и 1937. године, „који су омогућили очување највећег дела песничких вредности оригинала“. Наводећи оригиналне стихове уз превод, она истиче версификацијске и лексичке доминанте које су у преводу остварене, као и „елемент бесконачности из наслова“, оличен у многим метафорама и синтагмама.

Четврта целина ове публикације посвећена је песничком опусу С. Миличића: темама попут донжуанизма и музичких елемената у његовој првој збирци, феномена радости и вечности, поетске религиозности разапете између догматског католицизма и пантеизма и његове активности у часопису Мисао, који је први сабрао текстове о космизму. М. Ђурић у раду „Величајна’ граница модернистичког Дон Жуана у делу Сибета Миличића“ показује суштинску важност оригиналног начина разрачунавања с митологизованом фигуром Дон Жуана оствареној у Миличићевој другој збирци песама Десей ијјесама о Дон Хуану (1911). Ауторка посебну пажњу посвећује интермедијалном плану овог песничког текста, издвајајући вишеструку употребу различитих метричких и тоналитетских одредница у музичком и писаном делу, закључивши да се оваквом хибридношћу текст приближава либрету Моцартовог Дон Ђованија. Лирским субјектом и „динамиком унутарњег“ бави се А. Пауновић („(He) остварива радост у песничком делу J. С. Миличића: 'Од клика до

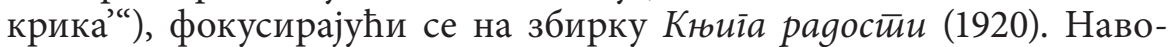
дећи темељна теоријска схватања феномена радовања, жеље, плоти (Марион, Батај), ауторка наводи да се појам радости код Миличића испољава као изузетно слојевит и поливалентан, нарочито у светлу

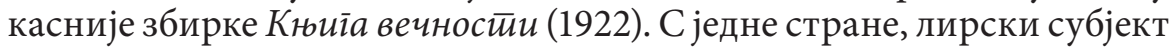
задивљен је природом, њеном непропадљивошћу и интуитивним осећањем космичког поретка у готово хришћанском расположењу, а с друге стране занет је „поетиком тела“, телесног и чулног чије ослобођење види једино у Другоме. Овом „инспирацијом боготражитељства“ бави се у свом раду и М. Радуловић („Поетска религиозност Сибета Миличића“), који њен распон сагледава од идеја авангардних поетика па до званичне хришћанске религиозности. Ова религиозност је, међутим, вишеструко интонирана и има наносе и космизма и пантеизма, али и догматске, црквене, хришћанске и вероисповедне мисли. Аутор сматра да су ови доживљаји духовности у раним Миличићевим збиркама супротстављени, да би у каснијим дошло до њихове синтезе, чиме ова поезија постаје специфична: она која претендује да изрази одређене нове, послератне духовне вредности 
које надрастају артистичке узусе. Рад С. Бараћ „Космизам Сибета Миличића у контексту часописа Мисао“ закључује овај део зборника, а посматра ауторско Миличићево присуство у југословенским часописима раних двадесетих година XX века, нарочито у часопису Мисао. Овај часопис, својевремено профилисан као „књижевно-политички“, савременом проучаваоцу пружа хронолошко читање текстова космолошке тематике, који су обухватали не само уметничке дисциплине већ и науку, филозофију, па чак и свакодневицу. Космизам се као доминантан поглед на свет појављује код великог броја уметника авангардног Београда (Црњански, Токин, Петровић, Манојловић, Винавер, Краков, Дединац), али С. Бараћ подсећа да Александар Илић 1922. године износи став да једино Миличић „међу свим космичким песницима има потпуно изграђену лирску космологију“.

Пета, последња и најобимнија целина зборника је о прозним делима Јосипа Миличића. Отвара се радом С. Петаковића „Иронијско развође збирке Борови и маслине“ који нуди поетичко-стилску анализу средишње приповетке „Зидање храма“ из поменуте збирке, својеврсног прозног триптиха, указујући на сложеност и хибридност приповедне технике (анегдота, иронија, контраст), и њену стилистичку специфичност унутар целокупног Миличићевог опуса. П. Петровић се у тексту „Модернистичка криза идентитета у роману Величанстивени бели брик Светии Јурај“ бави његовим јединим, више натуралистичким него авангардистичким романом (1928) у кључу психолошког/психоаналитичког читања, уз суд да „иако не спада међу најбоља остварења међуратног модернизма, Миличићев једини роман занимљив је у контексту интересовања тадашње прозе да артикулише борбу човека са силама немерљивим [...] или да пред-

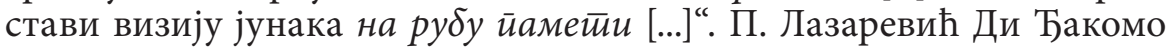
анализира формално и композиционо занимљиву Хронику йойонулоі осйрва у светлу идеје затвореног простора, друштвеног микрокосмоса који наговештава неизбежну апокалипсу, упркос мору као иманентном не-простору који окружује острво. Ауторка истиче да је реч о делу-утопији чија је формална структура нераскидиво повезана с тематиком и које као такво „представља јужнословенски пример инсуларне књижевности и књижевне антропологије, до тада увелико развијене у европским литерарним срединама“, чиме се наглашава прогресиван карактер Миличићевог деловања у оквирима југословенске књижевне сцене. Овом делу зборника припада и текст о занимљивом проблему језика и Миличићевој употреби дијалеката у зависности од стваралачке и животне фазе - чакавштине раног детињства, хрватске књижевне штокавштине, српске књижевне штокавштине, те повратак хрватском језику, повезаном с чежњом за завичајем (А. Капетановић, „Језични итинерар Сибе Миличића“). У средишту овог рада, поткрепљеног примерима из Си- 
бетових текстова, јесте посматрање и анализа преображаја његове употребе језика коју аутор доводи у везу с одређеним биографским и политичко-историјским околностима, закључивши да се Миличић „између хрватскога и српскога водио врло прагматично“. Зборник се закључује мултидисциплинарним радом С. Роић о синтези Сибетовог читавог уметничког, врло свестраног стваралаштва, с нагласком на музичком аспекту („Миличић од музике до мүิка“). Овај рад умногоме тематизује слична питања као и рад М. Ђурић из четврте целине ове публикације, а то је значај и статус музике у стваралаштву Сибета Миличића, нарочито подстакнутим пријатељством с композитором Благојем Берсом (1873-1934). У фокусу ове анализе налази се кратка прича $M \hat{y} \kappa(1914)$, структурирана у три приближно једнака дела. За сваки део, пише Роићева, карактеристични су специфични звукови, или, пак, њихово одсуство, што је сугерисано и самим насловом: први део обележен је шумом ветра, јаког маестрала који ствара звучно пенушање мора, други део започиње изненадним узвиком и криком старца, праћеним фијуком ветра, јаукањем жена и нарицањем над несрећним морнаром, док трећи део доноси оплакивање у селу и повик једног детета, а завршава се горким уздасима

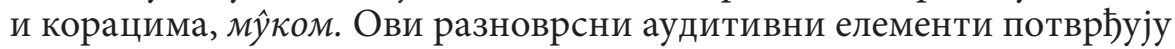
да се музика за Миличића „у непосредној форми очитовала у звуковима природе“.

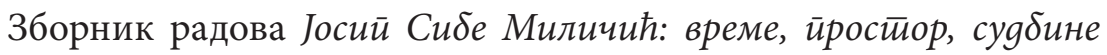
представља изузетно значајан допринос проучавању српског авангардног књижевног наслеђа, и то оног неочекиваног, скрајнутог, заборављеног или недовољно истраженог. Ових 19 радова нуди важна и подстицајна читања песничког и прозног дела Сибета Миличића, као и занимљиве увиде о животним и политичко-историјским приликама, чиме се он, коначно и заслужено, убедљивије позиционира у међуратној српској књижевности, где му и јесте место по језику и средини у којој је стварао, али чиме се не искључује из хрватске књижевности. Остаје нам да видимо који ће аутори српске књижевности XX века у будућности постати предмет проучавања ове нове, иновативне едиције, и уписати се у интердисциплинарне, културолошке и поетичке мапе Европе и Балкана. 